\title{
Technologie en organisatie : mythe en missie
}

Citation for published version (APA):

den Hertog, J. F. (1988). Technologie en organisatie : mythe en missie. Stichting Nederlands Instituut ter bevordering van de Kwaliteit van Werk en Organisatie (NKWO). https://doi.org/10.26481/spe.19880602jh

Document status and date:

Published: 02/06/1988

DOI:

10.26481/spe.19880602jh

Document Version:

Publisher's PDF, also known as Version of record

\section{Please check the document version of this publication:}

- A submitted manuscript is the version of the article upon submission and before peer-review. There can be important differences between the submitted version and the official published version of record.

People interested in the research are advised to contact the author for the final version of the publication, or visit the DOI to the publisher's website.

- The final author version and the galley proof are versions of the publication after peer review.

- The final published version features the final layout of the paper including the volume, issue and page numbers.

Link to publication

\footnotetext{
General rights rights.

- You may freely distribute the URL identifying the publication in the public portal. please follow below link for the End User Agreement:

www.umlib.nl/taverne-license

Take down policy

If you believe that this document breaches copyright please contact us at:

repository@maastrichtuniversity.nl

providing details and we will investigate your claim.
}

Copyright and moral rights for the publications made accessible in the public portal are retained by the authors and/or other copyright owners and it is a condition of accessing publications that users recognise and abide by the legal requirements associated with these

- Users may download and print one copy of any publication from the public portal for the purpose of private study or research.

- You may not further distribute the material or use it for any profit-making activity or commercial gain

If the publication is distributed under the terms of Article $25 \mathrm{fa}$ of the Dutch Copyright Act, indicated by the "Taverne" license above, 


\title{
Rijksuniversiteit Limburg
}

\section{TECHNOLOGIE EN \\ ORGANISATIE}

\section{MYTHE EN MISSIE}

\author{
Rede \\ uitgesproken bij de aanvaarding van het ambt van \\ buitengewoon hoogleraar in de Bedrijfseconomie \\ aan de Rijksuniversiteit Limburg \\ op donderdag 2 juni 1988 \\ door \\ J. Friso den Hertog
}

Uitgave: Stichting Nederlands Instituut ter bevordering van de Kwaliteit van Werk en Organisatie (NKWO) 


\section{Colofon}

Deze uitgave is mede mogelijk gemaakt door een bijdrage van de Stichting Nederlands instituut ter bevordering van de Kwaliteit van Werk en Organisatie.

Copyright: dr. J.F. den Hertog. Faculteit der Economische Wetenschappen, Rijksuniversiteit Limburg. 


\section{Dames en Heren,}

Jonge vernieuwende organisaties zijn in de voordelige positie, dat zij niet gebukt gaan onder de last van het verleden. Daar staat echter tegenover, dat zij bij voortduring worden uitgedaagd hun eigen positie te legitimeren en middelen voor het voortbestaan en groei veilig te stellen.

DeAmerikaanse sociologen Ritti en Silver (1986) laten zien, dat die organisaties zich bij de opbouw veelal succesvol bedienen van mythe-vorming. De mythe is een mengsel van waarheid, wijsheid en verzinsels. Zij levert ons voorstellingen over oorsprong, functie en doelmatigheid van een vernieuwing, die daarmee niet ter discussie behoeft te worden gesteld (Tblbert en Zücker, 1983). Het zijn deze mythes, die financiers en beleidsmakers het veilige idee geven, dat zij in hun beleid een goede zaak dienen en dat het geld wel zal worden besteed.

De Rijksuniversiteit Limburg, de Faculteit der Economische Wetenschappen en in het bijzonder het op 28 juni van dit jaar feestelijk te openen Maastricht Economic Research Institute on Innovation and Technology, MERIT, vormen geen uitzonderingen.

Ook hier is sprake van jonge organisaties, die vernieuwing in onderwijs en onderzoek hoog in het vaandel hebben staan. Het van de grond af opbouwen van een nieuwe faculteit en instituut met een eigen missie geeft in het verbureaucratiseerde en verstarde wetenschapsbedrijf kansen, die men niet aan zich voorbij mag laten gaan. Maar ook hier geldt, dat een vaste en legitieme plaats in dat wetenschapsbedrijf moet worden veroverd. Mythe-vorming biedt ook hier een effectieve weg voor institutionalisering.

Mythe-vorming is niet voldoende. De mythe moet worden uitgedragen. Dat gebeurt volgens Ritti en Silver vaak in rituelen, die niet van enig drama verschoond zijn en waarbij uitdragers en toehoorders de mythe bekrachtigen.

Het zou als wij deze visie volgen duidelijk kunnen zijn, waar- 
voor wij hier bijeen zijn. De oratie vormt een wetenschappelijk ritueel bij uitstek. Het biedt het uitgelezen moment om de eigen wetenschappelijke identiteit uit te dragen voor een publiek, dat bereid is de mythe met zijn aanwezigheid te bekrachtigen. Ik maak van deze gelegenheid gebruik $u$ voor het vervullen van deze sociologische functie te danken.

Hiermee mag enig licht zijn geworpen op de functie, van een oratie. Weinig is echter gezegd over de inhoud. Van de oratie wordt verwacht, dat inzicht wordt verschaft in de vorm en inhoud, die aan de aanvaarde leeropdracht wordt gegeven. De oratie krijgt dan zijn betekenis doordat zij verwijst naar een opdracht, een missie en een eigen positie binnen het wetenschapssysteem.

De recente oraties binnen onze jonge Faculteit leveren de contouren van de missie, die ons als collectiviteit voor ogen staat. De scherpste contour, die bij de oraties van Muysken, Schreuder, Hofstede, Van de Poel en Soete in het oog springt, is de integratieve in plaats van een segmentalistische benadering. Die integratieve benadering vormt de primaire voorwaarde voor succesvolle innovatie in onderwijs en onderzoek. Zij kenmerkt zich door de basishouding, waarbij men alvorens in een probleem te duiken eerst op een hoger systeemniveau naar de samenhang kijkt.

Die samenhang wordt in onze Faculteit gezocht in:

- de verbinding tussen disciplines;

- een internationale oriëntatie;

- de verbinding tussen wetenschap en praktijk;

- de programmatische aan pak van economisch onderzoek op onze drie aandachtsvelden: Technologie, Arbeid en de Publieke Sector;

- het probleemgerichte onderwijs.

In deze verhandeling staat de technologische vernieuwing binnen organisaties centraal. De kern van de redenering is, dat de enorme mogelijkheden van nieuwe technologieën pas effect sorteren, wanneer de organisatie daarop is ingericht. Allereerst. $\mathrm{zal}$ worden ingegaan op de mythe-vorming over de effectiviteit 
van de technologie en het contrast met de werkelikheid. Gewezen wordt op de noodzaak van een kwalitatieve omslag in het denken over organiseren. Die omslag vormt de basis voor het uitzetten van de vaarrichting voor organisatie-ontwerp en -beleid. Dat is de missie van de vernieuwende organisatie. Tenslotte zal worden ingegaan op de rol, die onderzoek hierbij kan en moet vervullen. Daamee ontstaat een beeld van de organisatiewetenschappelijke missie, waarvoor onze faculteit en het MERIT zich geplaatstzien.

\section{De mythe}

Een treffend voorbeeld van mythe-vorming, dat door Ritti en Silver naar voren wordt gebracht is de mythe van PERT. PERT staat voor Program Evaluation and Review Technique. Elke deelnemer aan een managementcursus of student in de organisatiewetenschappen wordt vroeger of later vertrouwd gemaakt met deze methode om projecten te plannen en de voortgang te volgen. De methode brengt de volgorde en afhankelijkheid van beslissingen en uitvoerende activiteiten in beeld en levert zo een meest verkiesbare route of "kritisch pad" op.

De PERT-methode (Ritti en Silver, 1986) is voor het eerst met groot succes gehanteerd in een complex militair project: het Polaris duikboten-project. De toepassing was zo succesvol, dat de PERT-methode daarna opgeld heeft gedaan als de managementaanpak van grootschalige ontwikkelingsprojecten.

Onderzoek (Guttman en Willner, 1976) laat echter zien dat het succes van het Polaris-project een andere oorzaak heeft, dan men uit de formele stukken kan opmaken. In dat onderzoek wordt vastgesteld, dat het net ontwikkelde PERT-systeem in hetPolaris-project in de kritische fase niet op grote schaal is gebruikt. Daar waar het wel werd gebruikt werkte het niet of werd er een geheel andere functie door vervuld, dan wordt vermeld in de officiële verslaglegging.

Dat betekende echter allerminst, dat PERT zijn nut niet bewees. Er moest indruk worden gemaakt op de financiers en het Congres: "PERT made us okay with the people who had the money. We did it in spades, computer, the whole bit" (Sapolsky, 
1972, p. 124). De onderzoekers concluderen, dat hoewel PERT niet van invloed is geweest op de doelmatigheid van het management, het zeker het vermogen heeft vergroot om aanvullende middelen bij het Congres los te krijgen.

Ritti en Silver verklaren deze ontwikkeling in theoretische termen: de PERT-mythe was, dat PERT een technische oplossing (engineering) vormdle voor een technisch (management) probleem. In werkelijkheid betrof het echter een institutionele oplossing voor het institutionele probleem van de legitimiteit van het project. Het gaat daarbij niet om de doelmatigheid van de organisatie, maar om de acceptatie bij de instanties, die de middelen beheersen.

De studie van Ritti en Silver doet denken aan projecten dichter bij huis. Ik denk bijvoorbeeld aan het relaas van een systeemanalist, werkzaam in één van de grote rijksdiensten. Hij deed mij verslag van een project in een informatieverzamelende en -verwerkende afdeling. De grotendeels handmatige systemen worden op voortvarende wijze van een automatiseringsplan voorzien. Het project loopt uit en men stuit op de bekende beheersings- en implementatieproblemen. Dat is op zich niet zo bijzonder: de Rekenkamer blijkt in haar verslagen over een haast onuitputtelijke verzameling van dergelijke projecten te beschikken. Dit project is echter illustratief, omdat blijkt, dat de informatie, die de afdeling verzamelt en verwerkt al jaren volkomen overbodig is. Ook hier biedt de technologie een oplossing voor een probleem. Dat probleem betreft echter niet het beter doen lopen van de betrokken diensteenheid, maar de legitimering van het voortbestaan van die afdeling.

Ik gebruik hier de overheidsautomatisering als voorbeeld, omdat de beleidsformulering en de verantwoording van beleid, zich veel meer dan bij bedrijven in de openbaarheid afspeelt. Als projecten uit de rails lopen bereikt dit nieuws zelfs de voorste pagina's van onze kranten.

De Rekenkamer heeft in de laatste jaren bijgedragen tot de transparantie van die ontwikkeling. De inspanningen van de Rekenkamer leveren een allesbehalve bemoedigend beeld. Er 
word op gewezen, dat informatievoorziening in alle geledingen van de overheidsorganisatie één van de belangrijkste processen is in het gehele overheidsfunctioneren en dat de betekenis van de automatisering daarin alleen nog maar zal toenemen. In haar verslagen (1984, 1985, 1986) laat de Rekenkamer tientallen projecten de revue passeren. $\mathrm{Zij}$ zet bij woortduring vraagtekens bij de efficiency van werken bij het opzetten, onderhouden en doen functioneren wan geautomatiseerde informatiesystemen. Een door haar verrichte wergelijking met het bedrijfsleven leert, dat men daarvergelijkbare problemen kent, maar projecten eerder staakt, wanneer zij vastlopen. Men accepteert liever een beperkt verlies, dan het risico te lopen te blijven voortmodderen.

De Rekenkamer stelt ons in 1986 wel gerust met de mededeling, dat de problemen met overheidsautomatisering nog niet tot calamiteiten hebben geleid. Ik neem aan, dat de Kamer in 1988 met het echec van de studiefinanciering achter de rugeen andere conclusie getrokken zou hebben.

De laatste jaren heeft de overheid duidelijk gemaakt welk belang aan de overheidsautomatisering wordt gehecht bij het verhogen van de doelmatigheid en de kwaliteit van het overheidsapparaat. Men denke aan het voornemen van de regering, de invoering van de informatietechnologie te versnellen. Het richtsnoer is (Tweede Kamer, 1984-1985, 18224, nr. 16) dat in 1995 de gegevensuitwisseling tussen alle geledingen van de overheid via datacommunicatie in plaats van via papier zal plaatsvinden. De hoge verwachtingen die men van overheidsautomatisering koestert spreken ook uit voornemens, die de overheid op specifieke beleidsterreinen uitspreekt. Bijvoorbeeld uit het voornemen om door automatisering de personeelsbezetting van de politie terug te brengen.

Opmerkelijk is echter, dat in dit krachtdadige beleid, waarin de informatietechnologie wordt gezien als de oplossing voor de problemen van de overheidsorganisatie praktisch voorbij wordt gegaan aan de feiten uit de praktijk, die de laatste jaren ter tafel zijn gekomen.

De mythe van de technologie is sterk. "Beat'em with technology or move-over there". Dat is de nieuwe Amerikaanse strijdkreet 
voor managers, die in de competitic met de Japanners hun hoofd boven water willen houden (Jaikumar, 1986). De technologie is alweer een aantal jaren apart terrein van staatszorg en verdient op tal van gebieden intensivering (Wissel tussen kennis en markt, 1987). In het economisch onderzoek (Soete, 1987 ) wint de overtuiging veld, dat technologie niet langer mag worden beschouwd als een exogene factor, als het residu dat overblijft wanneer de invloed van alle andere benoembare factoren is vastgesteld. Kortom: de zwarte doos van de technologie moet worden geopend. Het belang van technologische vernieuwing voor de economische vooruitgang staat niet ter discussie. Dat mythe-vorming in dit proces een belangrijke functie kan hebben evenmin.

De vraag, die wel voor ligt, is hoe men de afstand tussen mythe en de kennis en eryaring uit de praktijk wan de organisatie kan verkleinen. Daartoe eigent zich maarén weg: het openbreken van de $z$ warte doos van de organisatie.

\section{De omslag}

De stroom van empirisch onderzoek over de effectiviteit van technologische vernieuwing en de factoren, die op dit proces van invloed zijn begint de laatste jaren op gang te komen. Allereerst is echter de vraag gerechtvaardigd, in hoeverre de technologische ontwikkeling de organisatie in deze tijd voor unieke problemen plaatst. Wat is er zo specifiek aan de huidige ontwikkelingsfase van bedrijven en instellingen?

De stelling wordt hier verdedigd, dater sprake is van een kwalitatieve omslag in de situatie, waarin organisaties zich bevinden. Die omslag is te zien als de afwijking van een liniaire evolutie en vindt zijn oorsprong zowel in de endogene ontwikkeling van de technologie als in de veranderingen van de eisen, die de omgeving aan organisaties stelt.

Op de eerste plaats is er sprake van een lempoversnelling. Die tempoversnelling leidt ertoe, dat er in de organisatie weinig meer constant blijft dan de verandering zelf. In het achter ons liggende tijdperk lag de nadruk sterk op het optimaliseren en 
handhaven van de evenwichtstoestand: desteady state. Aan het eind van de tachtiger jaren zijn wij terecht gekomen in een periode waarin de spelregels van produkt- en procesvernieuwing (Takeuchi en Nonaka, 1986) zijn veranderd. De noodzaak van verbetering van kwaliteit, levertijden en verlaging van de kostprijs (en wel in die volgorde) drukt bij voortduring op de organisatie. Het competitieve spel verplaatst zich echter vooral naar het in de markt brengen van nieuwe produkten en het aanlopen van nieuwe processen. Het begin van de levenscyclus van het produkt moet beter worden uitgebaat. Jaikumar (1986) gaat zelf zover, dat hij in de nabije toekomst de fabricage als servicefunctie ziet met produkt-en procesvernieuwing als primair proces.

Op de tweede plaats heeft de kwalitatieve omslag betrekking op de factor ruimte. Vernieuwingen waren in het verleden vaak duidelijk te plaatsen in voorspelbare en duidelijk af te bakenen delen van het produktie-proces.

Het is met name de informatietechnologie, die enorme mogelijkheden biedt functionele en produktgebonden grenzen te overschrijden en produkt- en processtromen te integreren. Die grenzen tussen functies staan niet alleen onder druk in de uitvoering, in het primaire proces. Ook de professionele groepen, die het innovatieproces moeten dragen (marketing, produktontwikkeling, bedrijfsmechanisatie, industrial engineering, materials management en fabricage) worden geconfronteerd met ontwikkelingen, die haaks staan op de historisch gegroeide organisatorische afbakeningen .

De stroom van emiprisch onderzoek, die een inzicht geeft in deze omslag, groeit gestaag. Hier zal kort worden ingegaan op een aantal illustratieve studies. De eerste studie heeft betrekking op het gebruik van Flexibele Manufacturing Systemen (FMS). Jaikumar (1986) vergeleek 35 FMSystemen in de Verenigde Staten met 60 in Japan. De studie leert, dat in de V.S. de systemen op de verkeerde manier gebruikt worden: voor relatief grote series bij een geringe produktvariëteit, in plaats van voor kleine series bij grote variëteit tegen lage kosten. De Amerikaanse systemen zijn inflexibel. Die inflexibiliteit valt in diton- 
derzoek zeker niet toe te schrijven aan de apparatuur, de aard van het produktiepakket of aan de hoogte van de investeringen. Opmerkelijk is bovendien, dat de Japanners zorgen voor een veel effectievere machinebelasting ( 84 tegenover $52 \%$ ) dan de Amerikanen. Tenslotte kost het de Japanners aanmerkelijk minder tijd, om het systeem te implementeren en op volle kracht te laten draaien.

Jaikumar geeft de volgende verklaring voor de vastgestelde verschillen.

Op de eerste plaats wordt voorbij gegaan aan het feit, dat technologische vernieuwing meer inhoudt dan de investering in apparatuur. Succes komt alleen voort uit een continu leer-en experimenteerproces. De voortdurende druk op machinebezetting in de V.S. voorkomt, dat er tijd wordt genomen om verbeteringen aan te brengen. Als de machine eenmaal draait, mag niemand er met zijn vingers aankomen. Het resultaat is dat men het systeem niet in zijn vingers krijgt, het langer stil ligten de bezettingsgraad lager is. Het klinkt paradoxaal: de Amerikaanse druk op machinebezetting leidt tot een lagere bezetting. Een tweede factor, waarop Jaikumar wijst is de rigiditeit, waarmee men in de Verenigde Staten vasthoudt aan mechanistische organisatieprincipes. Management blijft gevangen in het Tayloristische denken en benadert de hoogwaardige technologie als "just another set of machines for high-volume standarized production." Dit betekent dat men volgens de grondslagen van het Scientific Management de scheiding tussen denken en doen blijft koesteren. Gevolg is, dat het niveau van het uitvoerend personeel afdaalt van vakman tot operator en dat de regelcapaciteit dicht bij het proces wordt verminderd.

De studie van Jaikumar doet mij denken aan de multinational, die drie jaar geleden besloot miljoenen te investeren in de bouw van een proeffabriek om daar nieuwe processen en produkten produktierijp te maken voor andere fabricage-centra. Het bedrijf bemant de fabriek met een doorgewinterde ploeg, doorkneed in de kunst van de fabricage. Binnen twee jaar is het duidelijk geworden, dat de constructie niet werkt: men is niet instaat de technologische aanloopproblemen drastisch te reduce- 
ren. De fabriek wordt gestuurd als een gewone, weliswatr dure fabriek, die model moet staan in termen van doelmatigheid. Van de leer-en on twikkelfunctie komt weinig terecht. Hier ga ik overigens voorbij aan de vraag of een dergelijke gecentraliseerde ontwikkeling decentraal wel zijn wruchten af werpt.

De tweede studie heeft betrekking op de effectiviteit van productontwikkeling en de rol daarbij van computer ondersteunde ontwerp-en fabricagesystemen (CAD/CAM) (Adler en Helleloid, 1986). Uit die studie kom naar voren (figuur1) dat de effectiviteit niet primair ahangt van de gekozen aanpak van het projectmanagement of van de aanwezige CAD/CAM-systemen.

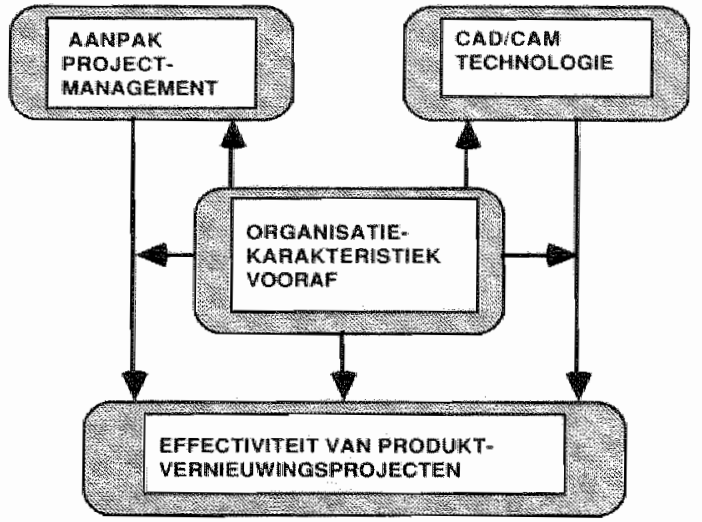

Figuur 1: Effectiviteit van produltontroikkeling

Dominant blijkt de karakteristiek van de organisatie, die vooral al gegeven kon worden. Eenwoudig gezegd betekent het dat een technologische integratie van functies het meest doelmatig verloopt, wanneer die vooraf organisatorisch al sterk zijn geintegreerd. Ook deze studie verwijst weer naar het leerver. mogen, zoals dat wordt belichaamd in de cultuur en structuur van de organisatie: "The greater the magnitude of technological change is sought, the higher the level of learning is required in the organization" (p. 102). 
Degedachte, dat technologie een zwaar stempel op de organisatie drukt blijkt in elk geval eenzijdig: de organisatie drukt haar stempel evenzeer op de technologie, of tenminste op de wijze waarop die technologie wordt gebruikt. Deze conclusie sluit aan bij een studie naar de invoering van computerondersteunde planningssystemen in mechanische werkplaatsen (Den Hertog en Wielinga, 1978). Met deze systemen kan in detail op mensmachine niveau worden gepland. De studie werd opgezet vanuit de verwachting, dat deze systemen in de organisatie een spanning laten ontstaan met het streven naar een grotere zelfstandigheid in de uitwoering. Het tegengestelde bleek waar. De effecten van de nieuwe systemen bleken de bestaande organisatiestijl eerder te versterken dan te doorbreken: bureaueratische werkplaatsen werden nog bureaucratischer, terwijl men in de meer flexibele werkplaatsen erin slaagde de eigen zelfstandigheid te versterken.

Rosabeth Moss Kanter (1983) laat in haar studie naar innovatie in organisaties zien, dat succesvol innoveren vraagt om een in. tegratieve denkwijze. Die aanpak richt zich op de organisatie als een geheel, op de vrije stroom van informatie en van ideëen dwars door organisatorische grenzen en op een strategische bezinning op de toekomst. De kernvraag daarbif is: "hoe ver moeten wij nog gaan". Zij plaatst deze denkwijze tegenover het segmentalisme. Daar is de leidende vraag: "Hoe ver zijn wij tot nu toe gekomen". Probleemoplossing betekent hier, dat men problemen in deelproblemen opsplitst en die toewijst aan afzonderlijke eenheden. Zo valt iedere betrokken eenheid een eigen doel en een eigen deel van het probleem toe. Deze locale rationaliteit staat in contrast met de aanpak, waarin men deelproblemen eerst aggregeert tot problemen van hogere orde om greep te krijgen op de samenhang.

In ons land is het vooral De Sitter en zijn groep (1986) geweest, diegewezen heeft op het gevaar van partieel on twerpen en op de noodzaak van een integrale benadering. Dat is overigens een benadering, waarin de technologie deel uitmaakt van het totale produlktieproces. De zwarte doos van de technologie, die recentelijk zo nadrukkelijk in de organisatiewetenschappen is 
geopend wordt door hem eerst weer gesloten, om in het totale werband van de produktiestroom te worden geplaatst. De strategische analyse levert in zijn opvatting de functionele eisen, waaraan het herontwerp van de organisatie moet voldoen. Dat zijn de eisen, die vanuit die omgeving (arbeidsmarkt, afzetmarkt, milieu), maar ook van binnenuit (kwaliteit van arbeid en organisatie) worden gesteld.

\section{De vaarrichting}

De vraag, die voor ligt is, hoe wij in ons land concrete vorm en inhoud kunnen geven aan een integrale sociale en technologische vernieuwing in organisaties. Dat is immers het loffelijke doel, dat ons door bedrijven, vakbeweging, overheid, advies-wereld en wetenschap wordt voorgehouden. De voorgaande analyse heeft een eerste aanwijzing gegeven van de koers, die wij in onze bedrijven en instellingen moeten varen. De kaarten, voor zover die beschikbaar zijn, tonen vele lege plekken. Een aantal bakens is echter aan te geven. Bij het uitzetten van die bakens is het van belang de stroom (of het proces) van de verandering te volgen. Het gaat hierbij om drie hoofdstromen (figuur 2): de strategie-ontwikkeling, het innovatieproces en het vervaardi-

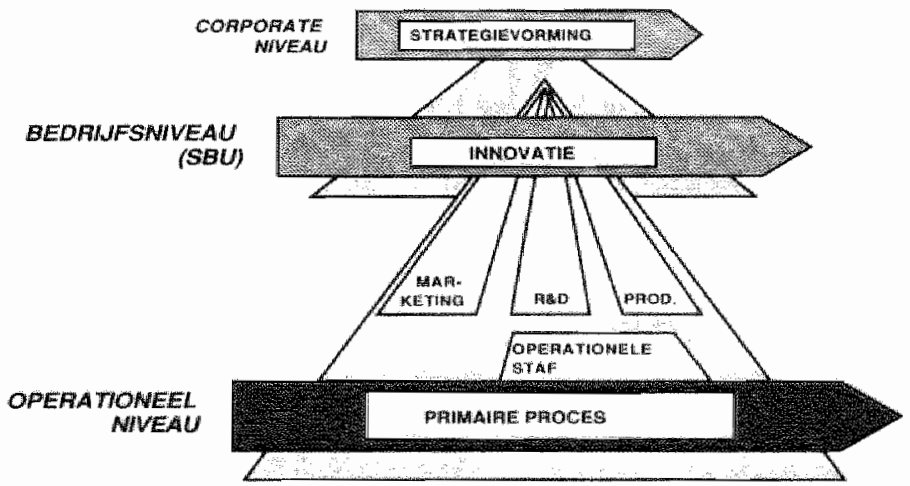

Figuue 2: Drie hoofdstromen 
gingsproces of primaire proces. Met een dergelijke stroomsgewijze benadering kijkt men over grenzen van taken, afdelingen en hiërarchische structuren heen.

Op het strategisch niveau is niet alleen de produktrnarkt mix aan de orde. Het strategisch management zal in de komende jaren evenzeer voor de keuze van technologie-organisatie mix geplaatst worden. De tijd ligt achter ons, dat de technisch-organisatorische infrastructuur alleen als afgeleide van produktmarktbeleid kon worden beschouwd. Bij andere gelegenheden zal ik nader op dit onderwerp ingaan. Laten wij werder ingaan of inzoomen op de twee volgende systeemniveaus.

\section{Herontwerp van het primaire proces}

De effecten van technologische vernieuwing worden vooral zichtbaar in de fabricage. Daar hebben proces en produkt concrete vorm aangenomen en is de innovatie zichtbaar belichaamd. Daar wordt ook duidelijk of machines handelbaar en produkten maakbaar zijn. Wij hebben de laatste twee decennia geleerd, dat de kwaliteit van het produkt, prijs en levertijd maar gedeeltelijk afhangen van de technologie. Kwaliteit van arbeid en organisatie drukken daarop evenzeer hun stempel.

Uit het onderzoek, dat sinds het begin van de jaren zeventig is verricht (De Sitter, 1981, Van Assen en Den Hertog, 1984) komen twee wezenlijke conclusies naar voren. De eerste is, dat technologische vernieuwing keuzemogelijkheden in zich draagt. Er is in die ontwikkeling een marge waarbinnen alternatieven kunnen worden afgewogen. Integraal ontwerpen betekent echter meer. Het betekent, dat de externe en interne eisen vertaald worden in ontwerpeisen voor het produktiesysteem als geheel.

De tweede conclusie heeft betrekking op de inrichting van het vernieuwingsproces. $\mathrm{Bij}$ het herontwerp is het van essentieel belang, dat geput wordt uit de deskundigheid, die in de organisatie aanwezig is. De belangrijkste deskundigheid is die van mensen over het werk dat zij uitvoeren. Problemen moeten worden overwonnen, zo dicht mogelijk bij de plek waar zij ontstaan. 
In de afgelopen jaren is in de adviespraktijk gebleken, dat de sociotechnische aanpak volwassen is geworden en reele alternatieven biedt aan bedrijven. Die aanpak rust op een viertal pijlers.

De eerste pijler wordt gevormd door een duidelijke visie op de organisatie en de gemeenschappelijke taal, die de systeembenadering oplevert. De bedrijfsdirecteur, administrateuren operator leren met dezelfde bril naar de organisatie te kijken. De tweede pijler is de strategische gerichtheid. De eisen voor het organisatie-ontwerp worden afgeleid uit een strategische oriëntatie op externe kansen en interne mogelijkheden.

De eigen verantwoordelijkheid voor het (her)ontwerp van leden van de organisatie op verschillende niveaus vormt de derde pijler. Het is niet de adviseur, maar de organisatie zelf, die de diagnose stelt en de therapie voorschrijft. De adviseur leert de organisatie het herontwerp zelf ter hand te nemen. Eien zeer intensief opleidingsplan vormt dan ook de vierde pijler.

\section{Management van technologische vernieuwing}

Technologische vernieuwing is een proces, dat niet alleen manifest wordt op het niveau van het primaire proces. In het hele proces van technologische vernieuwing betekent het in feite de laatste fase: die van invoeringen toepassing. De meeste technische en organisatorische keuzes zijn dan al impliciet of expliciet gemaakt. Daar komen de problemen naar voren, die in het voortraject zijn ingebakken.

"Slechte kwaliteit moet niet achteraf worden uitgeselecteerd; goede kwaliteit moet wooraf worden ingebouwd" (designing in, not selecting out). Dat is een moderne slagzin uit de kwaliteitszorg, die niet alleen betekenis heeft voor de kwaliteit van het produkt, maar ook voor die van werk en organisatie.

Het competitief vermogen van een onderneming blijkt (Jaikumar, 1986, Takeuchi en Nonaka, 1986) meer en meer afhankelijk van de wijze waarop men het voortraject in de vingers heeft. Van wezenlijk belang is hier de vraag of wij te maken hebben met een uitgeklede fabriek zonder eigen ontwikkelcapaciteit en 
zonder eigen relatie met de afnemers of met een compleet bedrijf, dat een eigen koers kan varen. Uit de adviespraktijk blijkt hoe moeilijk het is continuiteit te geven aan produktie-centra, die ver van de markt en van de technologische ontwikkelingsbron afstaan. Zij raken voortdurend buiten adem door de stroom van veranderingen, die van buitenaf wordt aangedragen. In het organisatie-ontwerp dient de vorming van complete bedrijfsstructuren in mijn visie als vertrekpunt te worden genomen.

Binnen die structuren is het samenspel tussen de kernfuncties (marketing, R \& D, mechanisatie en fabricage) bijzonder kritisch.

De Japanners Takeuchi en Nonaka (1986) laten zien dat in het ontwerpen van nieuwe produkten het spel is veranderd van een estafette met duidelijk afzonderlijke fases in een rugbymatch. In dat spel beweegt het team zich als eén geheel naar voren en wordt de bal van voor naar achter gespeeld en omgekeerd. De ontwikkelingsfasen overlappen elkaar. De produktie wordt vroeg in het spel betrokken terwijl produkt- en procesontwerpers tot het eindsignaal blijven meespelen. Zij worden geconfronteerd met de problemen, die bijvoorbeeld in produktie en distributie ontstaan en kunnen weer profiteren van de ervaring die daar wordt opgedaan. Figuur 3 geeft een illustratie van de opeenvolgende fases, die een produkt doorloopt van ontwikkeling via mechanisatie tot fabricage.

SEQUENTEEEL

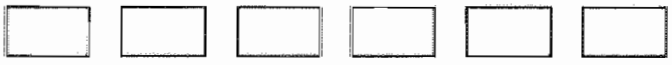

ONERLAPPEAD

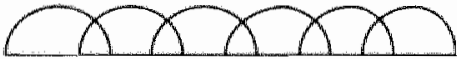

OVERLAPPEND

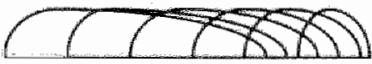

ONTWIKKELTTLO

Figuur 3: Overlappende ontwikkelingsfasen 
Dezelfde factoren, die tot verstarring leiden op het niveau van de uitvoering in het primaire proces stellen de grenzen aan de flexibiliteit en slagvaardigheid aan de top van de organisatie: functionalisering, hiërarchisering en het gebrek aan regelcapaciteit. Dat kan zowel gelden voor bedrijven, die onderdeel vormen van een groter concern, als voor toeleveranciers. Co-makership werkt op lange termijn bij hoogwaardige produkten en processen alleen wanneer er sprake is van een echte symbiose en de co-maker kan uitgaan van zijn eigen sterkte.

\section{De leerstrategie}

Als er in de recente management literatuur één boodschap duidelijk overkomt, dan is het, dat succesvol innoveren is gebaseerd op leren van fouten. Om voorop te blijven lopen moeten innovatoren van produktietechnologie beter zijn in leren dan hun concurrenten (Jönsson, 1987, p. 219). Het leren van succes (Maidique en Zirger, 1985) blijkt overigens nog heel wat lastiger. Succes kan leiden tot zelfvoldaanheid en de misvatting, dat de heroïek van het succes een verstandig bedrijfsbeleid overbodig maakt.

Het leerbegrip is in de organisatietheorie niet nieuw. Economen, psychologen, operations- en zelfs accounting researchers maken een vruchtbaar gebruik van het begrip organizational learning. Elke discipline en subdiscipline maakt echter op eigen specifieke wijze gebruik van het begrip. Door de economen wordt leren traditioneel gezien als een produkt van het fabriceren van grote aantallen en routinisering van handelingen met als resultaat het prijswoordeel. De psychologen hebben het leer begrip vooral verbonden met gedrag van individuen en interpersoonlijke relaties (Den Hertogen van Diepen, 1988).

Technologie en organisatie blijven in beide benaderingen zwarte dozen en abstracte begrippen. Juist op dat niveau liggen de keuzes voor strategie en herontwerp, kortom voor interventies in organisaties. Het is bovendien duidelijk, dat de toepassing van het leerbegrip zijn waarde juist heeft in situaties, waarin geen sprake is van routinematig handelen en waar interventies 
en doelenden het individuele niveau overstijgen. Nuttig is hierbij het begrip leervermogen. Dat is te definiëren als: het vermogen van een organisatie om relevante informatie te verzamelen, te selecterkn, te integreren, op te slacin en op te ropen, over te drogen en te gebruhen. De leerbenadering krijgt zijn waarde wanneer zij vertaald word in operationele doelen woor de meest relevante organisatorische domeinen:

- Personelsbeleid: Het personeelsbeleid kent een pallet van mogelijkheden om het leervermogen van de organisatie te verhogen: van het aantrekken wan talent, het bevorderen van horizontale mobiliteit, opleiden, tot het inzetten van materiéle belloningen.

- Organisatie ontwerp: Organisaties, waarin denken en doen, uitwoering en beheersing dicht op elkaar zijn gebonden en die sterk stroomgericht zijn hebben een groter leervermogen, dan bureaucratische organisaties, warin de functionele grenzen voortdurend barrières opwerpen.

- Ontwerpstrategieën: Het klassieke liniaire model van systeemontwerp blijkt steeds minder adequaat. De noodzalk van experimenteren met onrijpe produkten en processen, prototyping en van een iteratieve aanpak dient zich aan (Van Reeken, 1988).

- Evaluatie: De evaluatie vormt de laatste fase in elk handboek voor systeemontwikkeling. Juist aan deze terugkoppeling, die zo essentieel is voor het leereffect word in de praktijk het meest voorbijgegaan.

Management van technologische en organisatorische vernieuwing is in de kern cen proces van "readying the unready" . De weg is niet gemakkelijk: er zijn geen pasklare methodieken, gereedschappen en technieken. Partiele standaardbenaderingen bieden geen oplossingen. Een integrale benadering, zoals die in de sociotechnische school van De Sitter (1986) is ontwikkeld levert in elk geval een basis voor het uitzetten van de koers. Die weg kan echter niet alleen met structuren geplaveid zijn. Cultuurverandering is evenzeer aan de orde. Die kan alleen in gang gezet worden door een managementstij, die consequent bepaalde gedragspatronen in de organisatie versterkt. In die patronen is het toegestaan fouten te maken, maar ver- 
boden, daar niet de les uit te trekken.

\section{Ontwikkelen en Onderhandelen}

Technologie begint in de arbeidsverhoudingen een zwaardere rol te spelen. Het zijn vooral de effecten op de werkgelegenheid en in tweede instantie de gevolgen voor arbeidsomstandigheden en omscholing, die de vakbeweging tot een plaatsbepaling hebben aangezet (Aktieprogramma Arbeid en Technologie, 1987). De vakbeweging gaat ervan uit, dat technologische vernieuwing alleen maatschappelijk positieve effecten heeft, wanneer zij is ingebed in een proces van sociale vernieuwing. Daarover behoren volgens haar goede afspraken gemaakt te worden tussen de sociale partners. De overheid constateert daarbij, dat verhoging van deskundigheid en kennis bij vakbeweging en werknemers-vertegenwoordigers een bijdrage kan leveren aan een realistische besluitvorming (Tweede Kamer, 1986-1987).

Eén van de visies, die veelvuldig vanuit sociologische hoek naar voren wordt gebracht is, dat de technologie inderdaad keuzes op het gebied van arbeid en organisatie open laat, maar datelke verbetering in de arbeidssituatie moet worden afgedwongen (Callus, 1984). Daarmee wordt de zaak gereduceerd tot één van louter belangentegenstellingen en onderhandelen en de vastlegging in formele contracten of technologie-overeenkomsten. Er dreigt een vicieuze cirkel te ontstaan: management houdt de deur dicht en de vakbeweging klemt zich verder vast aan het formele onderhandelingsmodel. In Zweden drong het in het begin van de jaren tachtig tot de sociale partners door, dat er uiteindelijk geen winnaars maar alleen verliezers overblijven als men in dit spel blijft volharden. Men heeft daar naar nieuwe wegen gezocht, om de technologische ontwikkeling in positieve zin uit te baten. In 1982 heeft dit geleid tot een basisovereenkomst tussen werkgevers en werknemers. Die overeenkomst heeft geresulteerd in talrijke ontwikkelingsprogramma's voor onderwijs en herscholing, onderzoek en technologische en organisatorische vernieuwing in bedrijven. Binnen het 
krachtenspel van de arbeidsverhoudingen is ruimte geschapen voor vernieuwing en ontwikkeling. Opmerkelijk is, dat een dergelijk initiatief werd genomen juist in een tijd, waarin ook de Zweedse export voor grote problemen stond en de broekriem moest worden aangehaald. Het is nu zes jaar later. Het werikloosheidspercentage bedraagt in Zweden 2 tot $3 \%$. Misschien kunnen wij van de Zweden iets leren. In ons land beginnen op het niveau van industriéle bedrijven gelukkig openingen voor een dergelijke ontwikkeling te ontstaan. Ik denk hierbij aan bedrijven in de Rotterdamse haven als Swarttouw en Unitcentre.

\section{Ontwerpgericht onderzoek}

De vraag is aan de orde welk plan de organisatiewetenschappen nu moeten trekken om aan de gewenste ontwikkeling een bijdrage te kunnen leveren. Deze vraag is niet te beantwoorden met de obligate verwijzing naar nader onderzoek. Recente overzichtstudies en onderzoekevaluaties (Advies inzake onderzoek naar arbeidsvraagstukken, 1986, Blauwhof en Leydesdorff, 1986, den Hertog en van Assen, 1988) geven geen rooskleurig beeld van het onderzoek op het terrein van technologie, arbeid en organisatie. Gewezen wordt op verkaveling en versnippering van het onderzoek, de geringe theoretische en praktische meerwaarde, die de weliswaar groeiende stroom van onderzoek kenmerkt. Tegelijkertijd kunnen wij echter constateren, dat het belang van onderzoek op dit terrein in toenemende mate wordt onderschreven. Voor de minister van Onderwijs en Wetenschappen is dit aanleiding geweest om met zijn collega's van Economische Zaken en van Sociale Zaken en Werkgelegenheid het onderzoekstimuleringsplan Technologie, Arbeiden Organisatie (1986) te lanceren. De steun, die dit plan in ons parlement heeft gekregen vanuit alle fracties is verheugend.

De positie van het onderzoek op dit terrein is te illustreren aan de hand van figuur 4. 


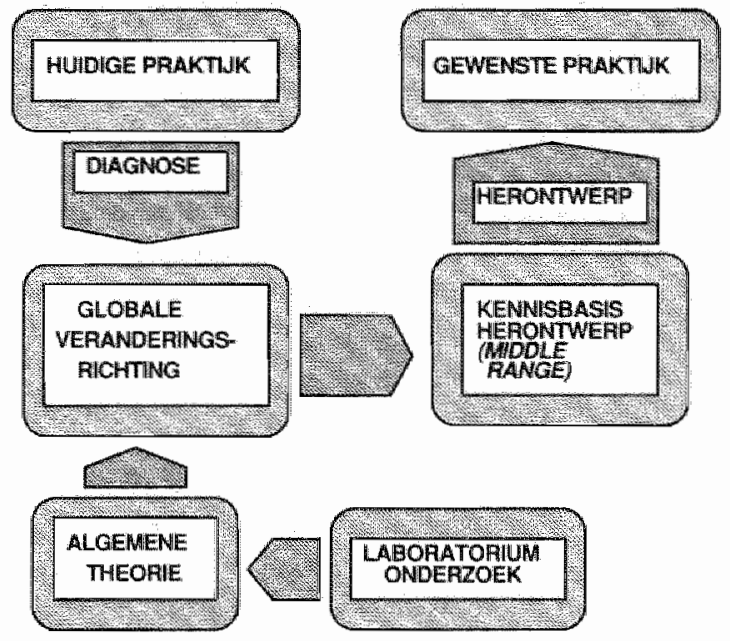

Figuar 4: De kenniscychss

Naar verhouding levert het onderzoek een redelijk globaal inzicht in de huidige problematiek in de praktijk: de geringe betrokkenheid van gebruikers en hun vertegenwoordigers in de besluitvorming, de partiele benadering van het ontwerp, het werwaarlozen van moeilijk te kwantificeren factoren in de financiële afweging en het nahinken van het personeelsbeleid. Dat beeld is hierboven reeds in ruwe lijnen geschetst.

Over de voorgestelde globale gewenste veranderingsrichting groeit de consensus evenzeer. Die consensus gaat, zoals wij hebben kunnen constateren in de richting van integraal en participatiefontwerp op basis van een strategische oriëntatie.

De grote leemte zit in de twee laatste schakels van de kenniscyclus: het opbouwen van een kennisbasis voor het (her)ontwerp en onderzoek in projecten, waarin een nieuwe iritegrale aanpak ook feitelijk wordt nagestreefd. Bij de op én na laatste schakel gaat het met name om strategieen, methoden, instrumenten en modellen, die integraal ontwerpen mogelijk maken. Aan de orde is bijwoorbeeld de omgevingsverkenning; de formulering 
van het document van ontwerpeisen, het maken van een opleidingsplan en de financiële onderbouwing van de keuze tussen ontwerpalternatieven. Bij de laatste schakel is de analyse van het veranderings proces en de meting van effecten aan de orde.

Tussen de praktijklessen van de klinicus aan de ene kant en de globale ideeën en modellen en het esoterische laboratoriumonderzoek aan de andere kant zit een groot gat. Er is behoefte aan goed empirisch basisonderzoek en theorievorming gericht op de ontwerppraktijk. Dit probleem in de kennisonderneming (Den Hertog en van Assen, 1988) is overigens kenmerkend voor de toegepaste wetenschappen, die zich richten op ingrepen in menselijke systemen. Het meest uitgekristalliseerd is die discussie in de geneeskunde, waar Sackett et al. (1985) zich inzetten voor de klinische epidemiologie als de basiswetenschap. Het gaat daar om onderzoek midden in de medische praktijk, dat een basis levert voor een betere diagnostiek en voor het ontwikkelen en uittesten van nieuwe therapieën. Een zelfde pleidooi vindt men binnen het empirische accounting onderzoek "....to study accounting in the context in which it oper. ates" (Hopwood, 1983) en in de operations research (Graham, 1984 .

Het opbouwen van een ontwerpgerichte onderzoektraditie is in het genoemde TAO-programma een centrale doelstelling. Die opgave vormt een uitdaging in een gesegmenteerd wetenschapsbedrijf, waarin disciplines, praktijk en theorie, onderzoek en onderwijs zo sterk aan middelpunt vliedende krachten onderhevig zijn geweest. Bij het realiseren van de gestelde opgave dienen zich een aantal essentiële condities aan.

Deeerste voorwaarde heeft betrekking op de mulidisciplinaire samenwerking. Op de eerste plaats binnen de organisatiewetenschappen zelf. De dialoog met de technische wetenschappen zal moeten worden gevoerd vanuit de eigen sterkte. Economen, informatici, sociologen en psychologen zullen moeten zoeken naar synergie en naar de complementaire bijdrage: naar hetgeen hen bindt in plaats van naar hetgeen hen scheidt. Een gemeenschappelijke taal en pers pectief vormen daarin een 
wezenlijk element. De sociotechnische ontwerpbenadering zou een dergelijk voertuig voor samenwerking kunnen vormen.

Het is niet alleen van belang, dat onderzoek zich richt op samenwerking tussen disciplines. De technologische ontwikkeling biedt ook aan birnen disciplines een aanleiding voor herbezinning op eigen uitgangspunten. Voor de economie in algemene zin is dit reeds verduidelijkt in de oratie van Soete (1987). Op tal van andere terreinen, arbeidsverhoudingen, personeelsbeleid, accounting en marketing dient een zelfde noodzaak van herbezinning zich aan (Den Hertog, 1988). Illustratief is in dit verband het pleidooi van Kaplan (1986) voor vernieuwing in de accountancy research. Zijn argument is, dat managers steeds meer beslissingen nemen op basis van geloof alleen, omdat de financiële beslissingsinstrumenten steeds minder steun bieden (zie ook: Den Hertog, Van de Poel en Roberts, 1986).

De tweede voorwaarde is organisatorisch van aard. Het ontwikkelen van een onderzoektraditie en het binden van disciplines vraagt om een organisatorisch $z$ waartepunt met een kritische massa en om een programmatische aanpalk. Organisatie en sturing van onderzoek zijn activiteiten, die op de werkvloer van de wetenschap met argwaan worden bezien. De dreiging van de bureaucratisering ligt steeds op de loer. Op een terrein, waar vernieuwing zo duidelijk wordt geremd door institutionele grenzen is een dergelijke aanpak echter essentieel.

Op de derde plaats moet worden gewezen op het belang van een goede verbinding met het praktijkveld. Hierin ligt juist de sterkte van de vergelijkbare Scandinavische programma's (The Swedish Center for Working Life: 1976-1987, 1987). In ons land ontbreekt het zeker niet aan individuele samenwerking tussen bedrijven, vakbeweging en organisatiewetenschappen. Op institutioneel niveau ontbreekt die samenwerking echter praktisch geheel. In de komende jaren, wanneer de organisatiewetenschappen orde op zaken stellen is een dergelijke institutionele samenwerking van wezenlijk belang. In de formulering van het technologiebeleid liggen tal wan mogelijkheden en absolute wenselijkheden om meer aandacht te besteden aan sociaalorganisatorische innovatie. Ik kan mij geen technologisch ont- 
wikkelingsprogramma, dat door de overheid mede bekostigd wordt, meer voorstellen, waarin geen verbinding wordt gelegd met ontwerpgericht onderzoek. Niet alleen in ideële, maar ook in materiële zin.

Tenslotte vraagt de ontwikkeling van de methodologie van ontwerpgericht onderzoek bijzondere aandacht. Klassieke stringente methoder van empirisch anderzoek bieden weinig soelaas in het onderzoek naar technologische en organisatorische vernieuwing. Daarmee is echter geen vrijbrief gegeven om aan elke eis van wetenschappelijke verantwoording voorbij te gaan. Bij het onitwikkelen van een onderzoektraditie van ontwerpgericht onderzoek zal veel aandacht moeten worden besteed aan het verkrijgen van hardere antwoorden met de zachtere methoden (Den Hertog en VanAssen, 1988).

Dames en heren, het is hopelijk duidelijk geworden dat de Rijksuniversiteit Limburg en in het bijzonder het Maastricht Economic Research Institute on Innovation and Technology meer voor ogen staat dan het ontmythologiseren van de technologie en het in stand houden van de eigen mythe. Ik heb de missie geschetst, die ons voor ogen staat: het opbouwen van een zwaartepunt van vernieuwend onderzoek op het terrein van technologie en organisatie. Die missie kan alleen vervuld worden in een hechte samenwerking over de grenzen van instellingen, disciplines, van wetenschap en praktijk en van landen. Een missie, die niet als een mythe boven discussie verheven is.

Het past hier tenslotte woorden van dank uit te spreken. Op de eerste plaats aan Hare Majesteit de Koningin, die mijn benoeming heeft bezegeld. Aan mijn ouders en schoonouders voor hun aanmoediging. Aan mijn vrouw, Ruby, die mij sterkte geeft en mijn vier kinderen, die mij nemen zoals ik ben. Aan Huub Vossen, Jan van Ham en Peter Tindemans, die mij respectievelijk het adviseurs-, onderzoek-en beleidswak bij brachten. Tenslotte gaat mijn dark uit aan de nestor van de geneeskunde, Andries Querido, die mij gezond heeft leren denken over de wetenschap van het klinisch handelen. 


\section{Bronnen}

Adler, P.S. en Helleloid, D.A. (1987). Effective implementation of integrated CAD/CAM:A model. IEEE Transactions on En. gineering Management. Vol. EM-34, no. 2, 101-107.

Advies inzake onderzoek naar arbeidsuraagstukken. (1986). Den Haag: Raad van Advies voor het Wetenschapsbeleid.

Aktieprogramma Arbeid en Technologie (1986). Amsterdam: Federatie Nederlandse Vakbeweging.

Assen,A. van en Hertog, J.F. den (1984). From job rotation to organization design. In: P.J.D. Drenth, H. Thierry, P.J. Willems en Ch. de Wolff (eds.) Handbook of work and organization psychology. Londen: Wiley.

Blauwhof, G. en Leydesdorff, L. (1986). Technologie en arbeidsorganisatie: De stand van het Nederlandse onderzoek, Resultaten van een inventarisatie. Zoetermeer: Ministerie van Onderwijs en Wetenschappen.

Callus,R. (1984). Self-managed research and technological change: Towards industrial democracy in an Australian public utility. Economic and Industrial Democracy, wol.5, 469493.

Graham, R.J. (1984). Anthropology and OR: The place of observation in management science process. Journal of Operational Research, vol. 35, no. 6, 527-536.

Guttman, D. en Willner, B. (1976). The shadow government. New York: Pantheon Books.

Hertog, J.F. den en Wielinga, C. (1978). The computer as an ink blot-test Eindhoven: Philips. 
Hertog, J.F. den en Assen, A. van, (1988). Methodologie van ontwerpgericht onderzoek. Maastricht/Eindhoven: RL/Philips.

Hertog, J.F.den, Poel, J. van de, en Roberts, H. (1986) Accounting in unprogrammable context: A search for economic measurement in the process of technological innovations in firms. Maastricht: EIAMS-paper.

Hertog, „.F. den en Diepen, B. van, (1988). Technological innovation and organizational learning. In: Bullinger (ed.), Management and information technology. Amsterdam: North Holland (verschijnt binnenkort).

Hertog, J.F. den (1988). Technologie, arbeid en organisatie in de industrie, Plan voor een onderzoekzwaartepunt. Maastricht: MERIT.

Hopwond, A. G. (1983). On trying to study accounting in the context in which it operates. Accounting, Organizations and Society. vol. 8, no. $2 / 3$

Jaikumar, R. (1986). Postindustrial manufacturing. Harvard Business Review, vol. 64, no. 6, 69-76.

Jönsson, S. (1987). Limits of information technology for facilitating organizational learning. In: J. M. Pennings en A. Buitendam. (eds.) New technology as organizational innovation: The development and diffusion of microelectronics. Cambridge, MA: Ballinger.

Kanter, R. M. (1983). The Change masters: Corporate entrepreneurs at work. Londen: Unwin.

Kaplan, R.S. (1986). Must CIM bejustified by faith alone? Harvard Business Review, vol. 64, no. 2,87-95.

Maidique, M.A. en Zirger, B.J. (1985). The new product learning cycle. Research Policy. vol.14, 299-313. 
Rapport van de Algemene Rekenkamer inzake overheidsautomatisering. (1985). Den Haag: Tweede Kamer (1985-1986, 19220, nrs. 1-2).

Reeken, T. van (1988). Naar een andere aanpak in de systemering. In: J.F. den Hertog en F.M.van Eijnatten (red.) Management van technologische vernieuwing. Assen: van Gorcum (verschijnt binnenkort).

Ritti, R.R. en Siver, J.H. (1986). Early processes of institutionalization: The dramaturgy of exchange in interorganizational relations. Administrative Science Quarterly, vol.31, no. 1, $25-42$.

Sackett, D.L., Haynes, R.B. en Tugwell, P. (1985). Clinical epidemiology: A basic science for elinical medicine. Boston: Little, Brown and Company.

Sapolsky, H. (1972). The Polaris system development: Bureaucratic and programmatic success in government. Cambridge, MA: Harvard University Press.

Sitter, L.U. de (1981). Op weg naar nieuwe fabrieken en kantoren. Deventer: Kluwer.

Sitter, L.U. de (red.)(1986). Het flexibele bedrijf. Deventer: Kluwer.

Sociale aspecten van technologische vernieuwing. (1987). Tweede Kamer(1986-1987, 20 037, nr. 2).

Soete, L. (1987). Technologie en economie (oratie). Maastricht: RL.

Takeuchi, H. en Nonaka, I. (1986). The new new product development game. Harvard Business Review, vol. 64, no. 1, 137146.

Technologie, Arbeid en Organisatie: Vitgangspunten 
voor een onderzoekstimuleringsplan. (1986). Tweede Kamer(1985-1986, 19542,nrs. 1 en 2.)

The Swedish Center for Working Life: 1976-1987. (1987). Stockholm:ALC.

Tolbert, P.S. en Zucker, L.G. (1983). Institutional sources of change in the formal structure of organizations: The diffusion of civil service reform, 1880-1935. Administrative Science Quarterly, vol.28, no. 1,22-39.

Verslag van de Rekenkamer over 1983 (1984). Den Haag: Tweede Kamer(1983-1984, 18313, nrs. 1-3).

Verslag van de Rekenkamer over 1984 (1985). Den Haag: Tweede Kamer (1984-1985, 18918, nrs. 1-3).

Wissel tussen kennis en markt (1987). Den Haag: De commissie Dekker. 